\title{
Short Communication: \\ Incidence of insect pest on planted Shorea macrophylla at reforestation sites in Gunung Apeng National Park, Sarawak, Malaysia
}

\author{
MOGERET BINTI SIDI ${ }^{1,2}$, MOHD EFFENDI WASLI ${ }^{1, \nu}$, ELFERA POLLY ${ }^{1}$, \\ AINA NADIA NAJWA MOHAMAD JAFFAR ${ }^{1}$, MEEKIONG KALU ${ }^{1}$, HAMSAWI SANI ${ }^{1}$, \\ HAFSAH NAHRAWI ${ }^{1}$, HASHIMAH ELIAS ${ }^{1}$, DZOLKHIFLI OMAR ${ }^{2}$ \\ ${ }^{1}$ Faculty of Resource Science and Technology, Universiti Malaysia Sarawak. 94300 Kota Samarahan, Sarawak, Malaysia. Tel./fax.: +60-8-2583001, \\ vemail: mohdeffendiw@gmail.com \\ ${ }^{2}$ Faculty of Agriculture, Universiti Putra Malaysia. 43400 Serdang, Selangor Darul Ehsan, Malaysia
}

Manuscript received: 14 August 2021. Revision accepted: 29 October 2021.

\begin{abstract}
Sidi MB, Wasli ME, Polly E, Jaffar ANNM, Kalu M, Sani H, Nahrawi H, Elias H, Omar D. 2021. Short Communication: Incidence of insect pest on planted Shorea macrophylla at reforestation sites in Gunung Apeng National Park, Sarawak, Malaysia. Biodiversitas 22: 5162-5168. Incidence of insect pest in Shorea macrophylla (de Vriese) P.S. Ashton had critical foliage damage in mono planting technique. The main objectives were to assess the foliage damage intensity of planted $S$. macrophylla by age stands and type of foliage damage. The insect pest attacks the foliage of $S$. macrophylla was determined. The study site was located at Gunung Apeng National Park (GANP), Sarawak, Malaysia, with planted S. macrophylla in enrichment planting at different years (planted in 2008, 2009, 2010, and 2011 for age stand 6, 5, 4, and 3, respectively). The results showed that the degree of foliage damage decreases with the age stand of $S$. macrophylla tree. Therefore, foliage damage was suspected to be caused by insect pests. Among the common foliage damages observed was "hole damage" caused by insect order Lepidoptera. Although foliage damage was significant, the severity of the damage will "heal" as the age stand increases. Further investigation on other possible causes of these pest attacks should be initiated to find solutions that may hasten the growth of planted S. macrophylla for forest restoration.
\end{abstract}

Keywords: Age stands, foliage damage, insect pest, Shorea macrophylla

\section{INTRODUCTION}

Damaging pests are commonly encountered in tropical plantations and natural forests. In a diverse forest ecosystem, it is widely understood that its stability allows the balance in species population to prevent one species from increasing. In a complex tropical rain forest, pests and disease infestations will remain stable due to limited suitable host materials. However, that may not be the case for mono species plantations where the species composition may provide a dominant species ecosystem that supplies an unlimited amount of host biomass for pests and disease that would marginalize the habitat for natural enemies (Nair 2007).

Defoliation is a condition of losing a small part or whole damage on the foliage by the pest. The continuation of defoliation reduced the production of foliage and shoot, dead on lower branches, scattered on tops caused ultimate death of upper branches and occasionally the entire tree (Battaglia et al. 2011; Cavaletto et al. 2019). The nutrient for tree development might deplete as the physical injury on the tree consecutively occurs (Wargo 1996; Marcais and Breda 2006). This situation lessens the ability of the tree to survive, making it prone to insect attack. The termites attacked the young Dipterocarp saplings in enrichment planting sites (Itoh et al. 1995; Kirton and Cheng 2007).
Gunung Apeng National Park (GANP), Sarawak, Malaysia, is one of the sites reforested through enrichment planting (Wasli et al. 2020). With the addition of planted indigenous trees into secondary forest areas through enrichment planting, there are abundant food and good breeding ground for various insect pest species (Itoh et al. 1995). The specific insect pest may defoliate the leaves, destroy the root and shoot, attack the stem and suck the sap in mono-species tree plantation abundantly. A possible increase in insect population can cause insect pest outbreaks in some cases, leading to the destruction of the planted forest area (Allard et al. 2003; Lee 2018; Prastyaningsih et al. 2020).

However, few reports were available on the insect pests incidence in reforestation areas after enrichment planting (Wormald 1992; Watt 1997; Aluja et al. 2014; Saunders et al. 2016). In Sarawak, Shorea macrophylla is considered a fast-growing tree species commonly planted for reforestation due to their profuse flowering and fruiting every year (Perumal et al. 2017a, b). The reforestation at GANP emulated this approach where S. macrophylla was planted for enrichment purposes where most of the area is planted via mono-species planting. It would be essential to study the incidence of insect pests of planted $S$. macrophylla at GANP. The data on the damaging trend of the tree is vital to formulate the most effective protection strategies. Thus, this study provides information on the 
insect foliage damage on S. macrophylla influence by age stands in mono planting technique. Information gathered will help select species suitability and manage enrichment planting for any reforestation project. Hence the objectives of the study were as follows: (i) To assess the foliage damage intensity of planted $S$. macrophylla by age stands; (ii) To determine the frequency of three different types of foliage damage (a hole, wrinkled, and folded) of $S$. macrophylla; (iii) To record causal insects affecting planted S. macrophylla in GANP.

\section{MATERIALS AND METHODS}

\section{Study area}

Gunung Apeng National Park (GANP) is located at Serian (N00o55'24.7", E110o38'32.2"), Sarawak, Malaysia. The study site has been one of the reforestation sites through enrichment planting since the year 2005. Approximately 700 hectares of the area had been planted with different types of indigenous species, including Dipterocarps trees such as Dryobalanops beccarii, Shorea parvifolia, and S. macrophylla. The detailed information on the reforestation activities at the study area was reported in our previous study (Wasli et al. 2020). The climate is tropical wet (no dry seasons) with subtropical wet forest biozone (Anon 2002). The native trees were left uncut within the plantation area during land clearing to provide shading for seedlings and maintain the environmental conditions for reforestation. The average temperature was ranged between $23^{\circ} \mathrm{C}$ and $33^{\circ} \mathrm{C}$. The mean annual precipitation was $3500 \mathrm{~mm}$ at Balai Ringin rainfall station near GANP (Department of Irrigation and Drainage 2010). The soil in the area is classified as grey-white podzolic soil based on Sarawak soil classification on the USDA classification system.

\section{Foliage damage assessment}

The foliage damage assessment was done by systematically observing every alternate line of the planted trees. The alternate rows were assessed for the presence of insect damage on the foliage. Five rows were evaluated, and each row had twenty trees for each age stands. The assessment includes observing and calculating the foliage symptoms caused by insects, such as wrinkled foliage and loss in foliage areas (including skeletonized and whole damage). Five different age stands were assessed for $S$. macrophylla; age 6 , age 5 , age 4 , and age 3 years, respectively.

The observation and assessment were done using binocular for the tree with a height of more than $2 \mathrm{~m}$, where most of the tall trees were at an average of $4 \mathrm{~m}$ for $S$. macrophylla. Since $S$. macrophylla foliage was more than $15 \mathrm{~cm}$ in length, the damage assessment was conducted using binocular or the naked eye for small trees. The percentage of defoliation damage per tree was calculated by following modified formula:

$$
\begin{array}{ll}
\text { DLpt } & \text { : Damage foliage per twig } \\
\text { TLpt } & \text { : Total foliage per twig } \\
\mathrm{Tt} & \text { : Total twig per tree }
\end{array}
$$

The defoliation's damage was compared among the tree species and by the age of the tree. The defoliation's damage was recorded as a percentage, and it was classified followed as Nair et al. (1986), classification: (i) $0 \%$ class as 0 (low damage); (ii) $1 \%$ up to $5 \%$ class as 1 (fair damage); (iii) $6-50 \%$ class as 2 (moderate damage); (iv) $51-100 \%$ class as 3 (high damage).

\section{Insect collection and foliage damage evaluation}

The insect collection and damage evaluation methods were modified from the method reported by Chung et al. (2013). The insect survey and monitoring were conducted within site planted with $S$. macrophylla. The number of foliage damaged by defoliators was recorded, and frequency or percentage of damage was calculated using the following formula:

\section{[Frequency of damage $(\mathrm{a} / \mathrm{b} / \mathrm{c})] /\left(\sum\right.$ Tree $) \times 100 \%$}

All adult insects or larvae feeding on the tree were collected and placed in a plastic container lined with tissue paper. The captured insects were photographed using Nikon D60 (NIKON, Japan) with a $52 \mathrm{~mm}$ lens for recording purposes. The adults and larvae were identified up to the family level. The identification of the insect specimens was based on pictorial images from references books and insect catalogues from the museum of Faculty Resource Science and Technology (FRST), UNIMAS.

The light trap was set up in the middle of the study plot to trap the sign of any insects that caused damage to foliage during night hours. The light trap was made of a cylinder plastic container, plastic funnel, killing jar (ethyl acetate soaked with tissue), and $160 \mathrm{~W}$ bulb (70 m light penetration). The light trap was collected after 4 hours.

\section{RESULTS AND DISCUSSION}

\section{Foliage damage incidence of Shorea macrophylla by different age stands}

Foliage damage of $S$. macrophylla caused by insects was assessed and valued in percentage and classified to different class damage. From Figure 1, the percentage of $S$. macrophylla trees with class damage 0 is higher at stand age 5 with $16.70 \%$ of tree and age 6 with $18.10 \%$ of the tree. Meanwhile, the tree with class 1 damage percentage was only recorded at stand age 6 years old with $2.80 \%$ trees. Percentage of $S$. macrophylla trees with class damage 2 increased from stands age $3(18.70 \%)$, age $4(48.70 \%)$, age $5(66.70 \%)$, and age $6(55.60 \%)$. The percentages of $S$. macrophylla stands with class damage 3 highly recorded at stands ages 3 and 4 . From the rate of tree recorded for each class of damage, the young stands of S. macrophylla at age 3 and 4 highly recorded with class damage 3 compared to stands age 5 and 6 of $S$. macrophylla. 


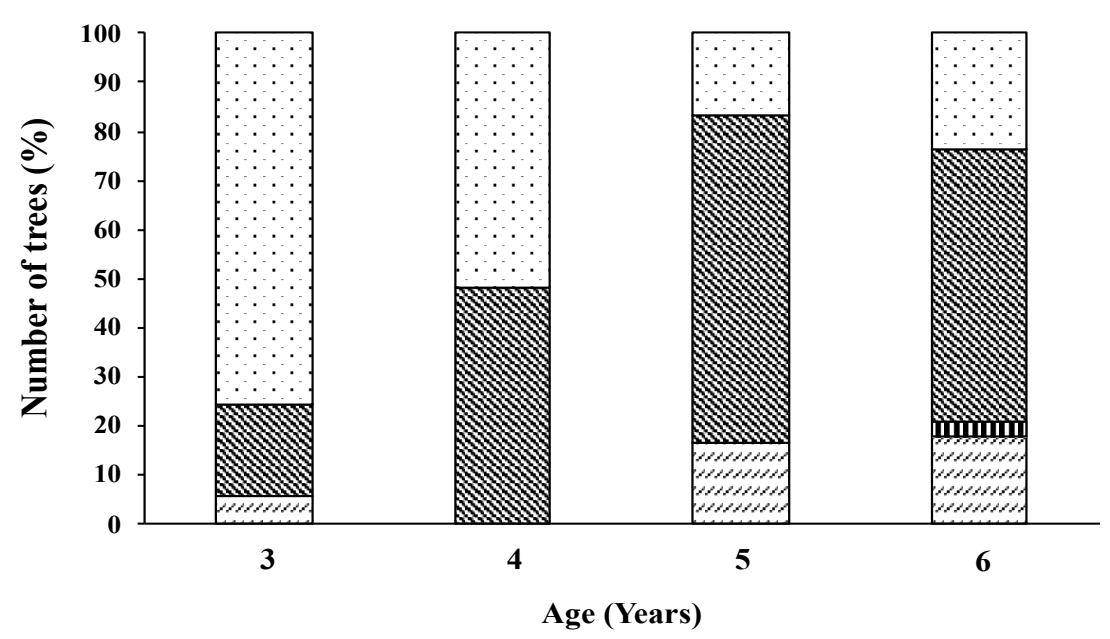

Legends:

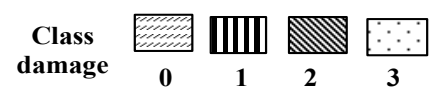

Figure 1. Percentage of trees with class damage defoliation by age

The mean foliage damage of S. macrophylla caused by the insect differs between all age stands (Table 1). The trees at ages 4, 5 and 6 were classified under moderate foliage damage or class 2 damage among the four different ages. The intensity of foliage damage was significantly higher at stand age 3 and 4 years old compared to stand age 5 , and 6 years old. Meanwhile, the foliage damage was low for stand age 5 and 6 compared to stand age 3 and 4 . There is no difference in foliage damage between trees at age stands from 5 to 6 .

The highest mean of foliage damage of S. macrophylla was recorded at age 3 by $63.18 \%$, and the lowest was recorded at age 5 and 6 at $33.44 \%$ and $33.73 \%$ of damage, respectively. Some $S$. macrophylla shared similar foliage damage occurrences such as reported by Daljeet-Singh (1975), showed that planting trial of Dipterocarp species of Shorea acuminata was $50 \%$ critically damaged on the shoot during early planting, however trees of Shorea parvifolia, Shorea ovalis, and Shorea leprosula, were only damaged in the range of $7.30 \%$ to $16.50 \%$.

Some studies reported that tree defoliation under temperate climate increases with increasing age because the younger tree was more sustainable at different ecological conditions and insects most likely damaged the broad foliage (Tubby and Webber 2010). The foliage of $S$. macrophylla is at a range of more than $15 \mathrm{~cm}$; thus, the physical appearance of foliage that is bigger in size may increase the insect attachment and increase the foliage damage and defoliation. Instead of tree height factors, nutrients content and foliage's defense structure may differ at different age stand. The young foliage may have higher nutrient contents than older foliage, and the young stand with younger foliage had a fewer structural defense than the older age stands (Lee et al. 1997). As reported in Howlett and Davidson (2001), the entire expansion foliage of S. leprosula and Dryobalanops lanceolate had low damage caused by insect pests during the seedling stage. Even though defoliation occurred during early planting, the tree could produce new leaves; as Aluja et al. (2014) discussed if the tree undergoes defoliation critically during an early stage, the tree will undergo refoliation or produce new foliage.

Factors such as tree spacing, tree height, and condition of ground litter can be ascribed to the potential insect pest attack for planted trees. Tho and Nohara (1983) reported that generally, insects are prone to attack the young shoots and twigs of several dipterocarps trees. With the presence and abundance of decayed leaves and bushes that mainly cover the forest floor of the Gunung Apeng (Wasli et al. 2014), such conditions would contribute to the breeding ground for pests to grow and breeds. Thus, the trees with younger age stand where their tree growth stages are still at the early stage of development may face a greater risk of damage and were critically fed by insect pests than taller cultivars (Morrisons et al. 2007).

Table 1. Mean of foliage damage (\%) of Shorea macrophylla by stand age

\begin{tabular}{ccc}
\hline Age & Number of tree (n) & Mean of foliage damage (\%) \\
\hline 3 & 107 & $63.18 \pm 25.60 \mathrm{a}$ \\
4 & 40 & $49.90 \pm 19.39 \mathrm{a}$ \\
5 & 43 & $33.44 \pm 33.96 \mathrm{~b}$ \\
6 & 72 & $33.73 \pm 26.67 \mathrm{~b}$ \\
\hline
\end{tabular}

Note: Means \pm standard deviation: values in the same column followed by different letters indicate significant differences among sites at $P<0.05$. 


\section{Type of foliage damage}

The survey on insect damage was focused mainly on the foliage. It was found that three primary forms of foliage damages were recorded, such as free feeding and "hole damage," "wrinkled foliage," and "folded or rolled foliage." Insect damaged some tree stems, but the number of stem damage was low and negligible. From Table 2, more than $50 \%$ damage of $S$. macrophylla was recorded with the "hole damage" (Figure 2). Based on our field observation, the damage occurred when the trees were raised in the nursery, and later, similar conditions continued to occur after transplanting. The "hole damage" included chlorotic spots and net-like damage on the foliage. Chlorotic spots are usually caused by toxic injection by the insect (Nair and Sumardi 2000). The "wrinkled foliage" was the lowest damage on average, below 3\%, while "rolled foliage" damage was second highest (21.48\%).

During the assessment, some insects were found inside of the "rolled" foliage and feed on the foliage. But they do not cause rolled foliage. Nair (2007) stated that bagworms or caterpillars lived inside the rolled foliage for protection or hiding place. One of the species bagworms (Order: Lepidoptera), Pteroma sp. is recorded, and it was recorded as the possible cause of skeletonized foliage, which may lead to dieback. Zulfiah (1998) indicated that an attack by bagworms on 5 years old crop plantation was critical and could be of concern in plant growth development. In addition, Nair and Sumardi (2000) recommended that regular thinning operations be carried out at trees ages 3,4 , 5 , and 6 years old by removing critical infested trees due to pests first to reduce the infestation rate from $4 \%$ to $10 \%$.

\section{Insect pest}

There are 15 various insect pests recorded on $S$. macrophylla trees of the study site (Figure 3). Among the encountered insect pests, the "hole damage" insect was the most common insect found in the study site. On the $S$. macrophylla tree, there were 13 pests categorized as the caused to "hole damage" and 1 insect for each damage for "wrinkled foliage" and "rolled foliage." The insects attacking S. macrophylla were from the order Lepidoptera (Noctuidae; 2 species, Lymantriidae; 3 species, Geometridae; 1 species, Arctiidae; 1 species, Limacodidae; 1 species), order of Coleoptera (Scarabaeidae, Chrysomelidae, Coccinellidae; 1 species), order Orthoptera (green grasshopper) and two unidentified insects (Figures $3 \mathrm{~m}, \mathrm{n})$. It was challenging to identify insect pests that caused rolled damage during the survey as the foliage was left empty with only their waste materials.

Table 2. Damages symptom (\%) on Shorea macrophylla based on year of planting (age)

\begin{tabular}{cccc}
\hline \multirow{2}{*}{ Year (age) } & \multicolumn{3}{c}{ Type of damage } \\
\cline { 2 - 4 } & Free feeding and hole damage (\%) & Wrinkled foliage (\%) & Rolled foliage (\%) \\
\hline $2008(6)$ & 84.72 & 0.00 & 9.72 \\
$2009(5)$ & 62.79 & 6.97 & 20.93 \\
$2010(4)$ & 97.50 & 5.00 & 52.50 \\
$2011(3)$ & 65.42 & 2.80 & 24.29 \\
Average & 77.61 & 3.69 & 26.86 \\
\hline
\end{tabular}

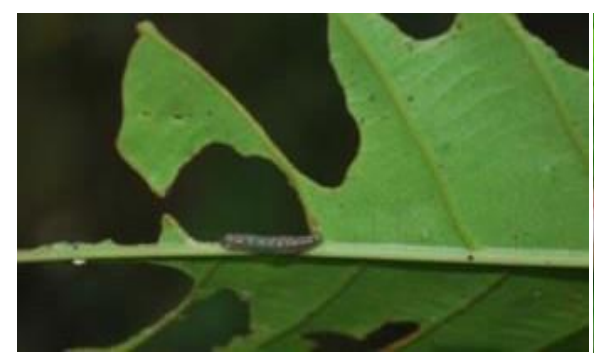

$\mathbf{A}$

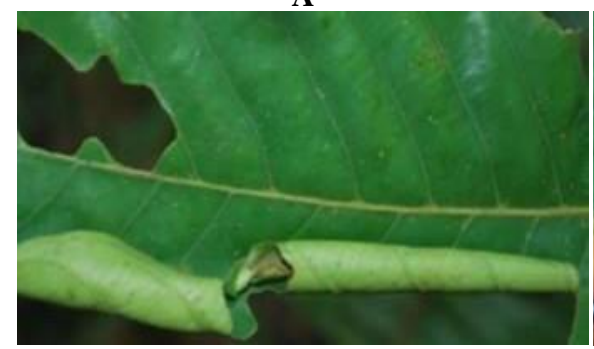

D

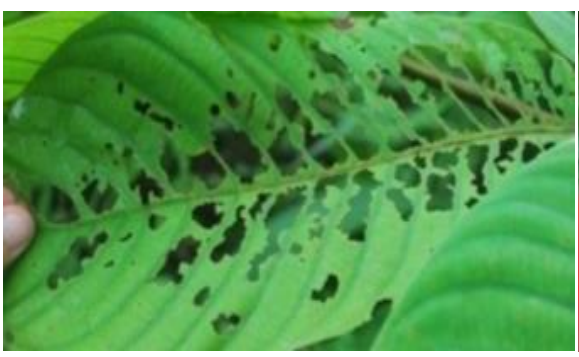

B

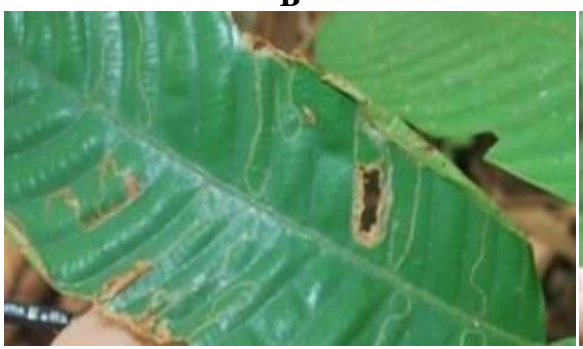

$\mathbf{E}$

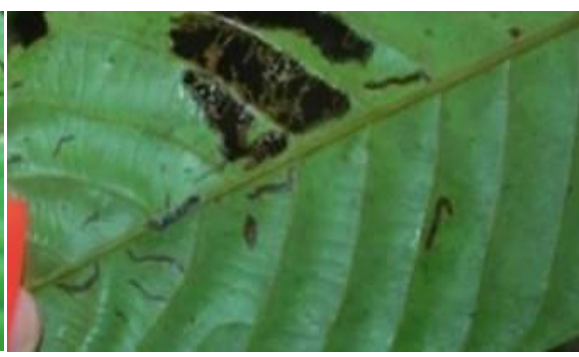

C

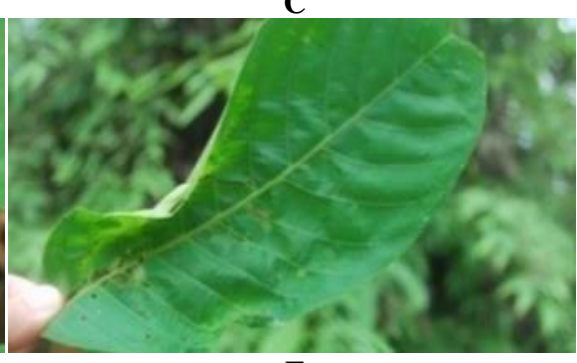

Figure 2. Symptoms of foliage damage by insect pest on Shorea macrophylla. A. Chlorotic spot; B. Net-like damage; C. Hole damage; D. Rolled foliage; E. Shot hole; F. Wrinkled foliage 


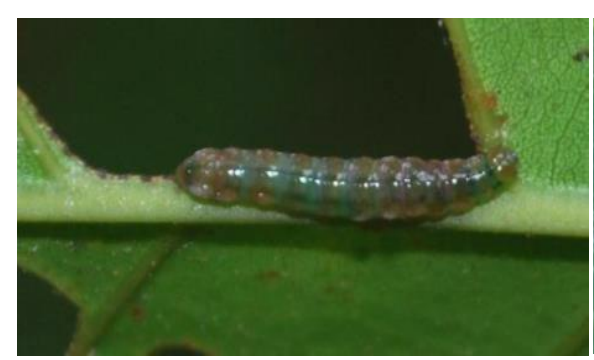

A

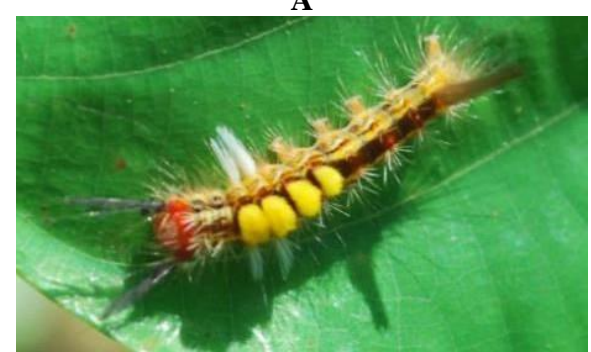

D

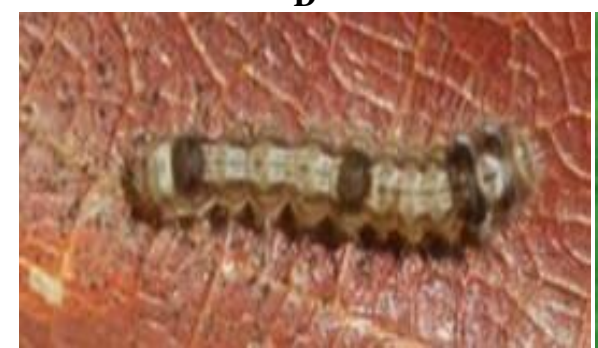

G

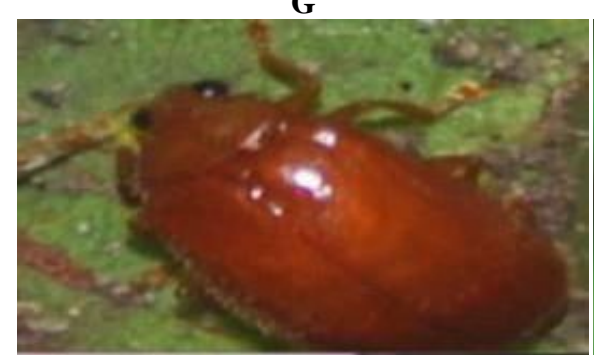

$\mathbf{J}$

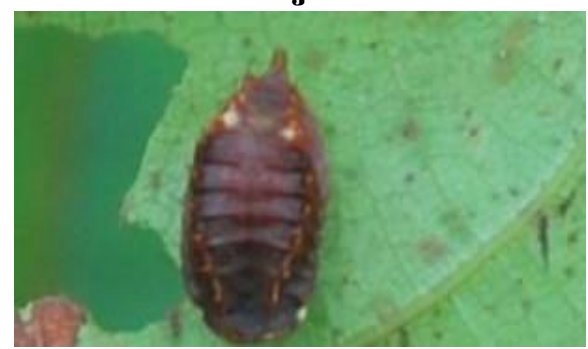

M

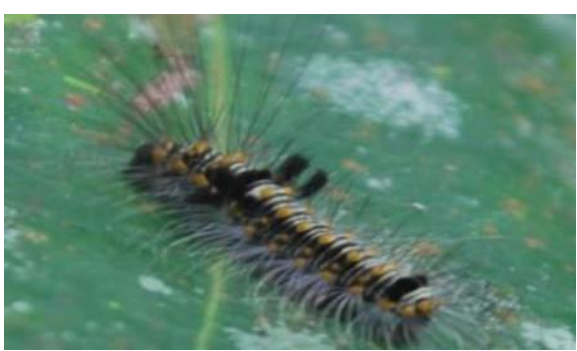

B

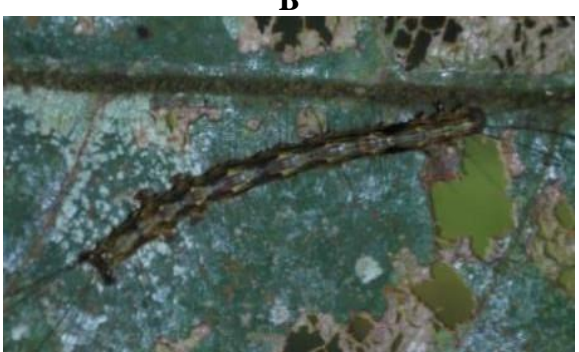

$\mathbf{E}$

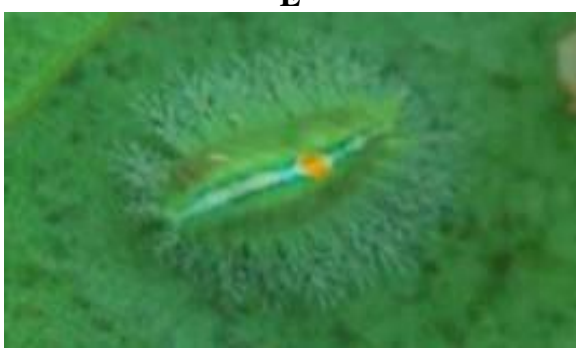

H

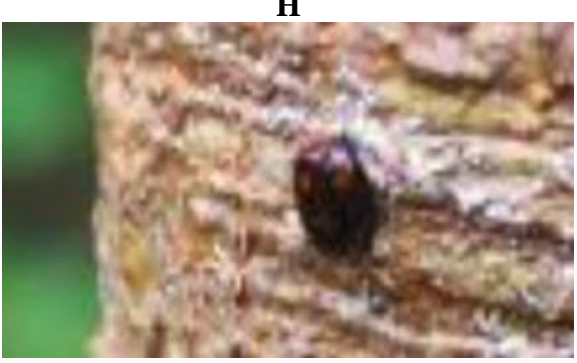

$\mathbf{K}$

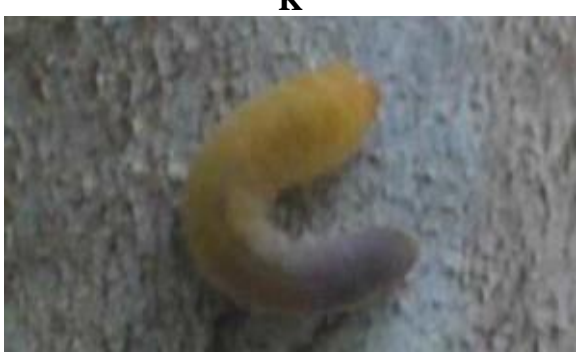

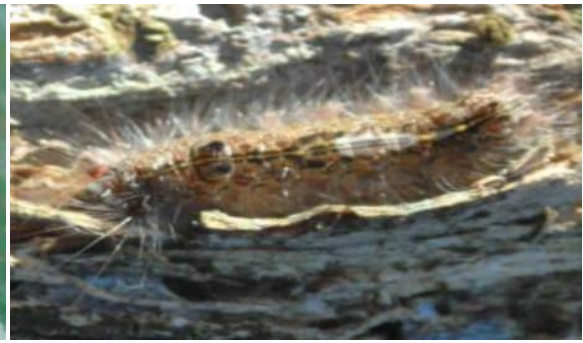

C

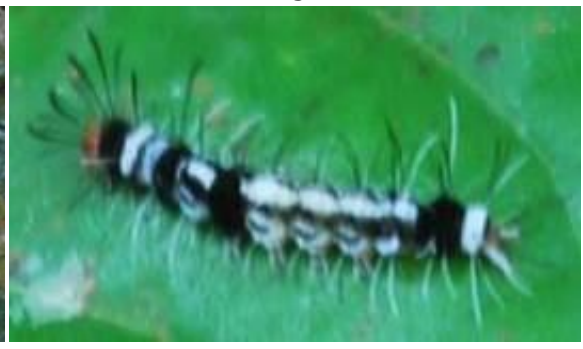

$\mathbf{F}$

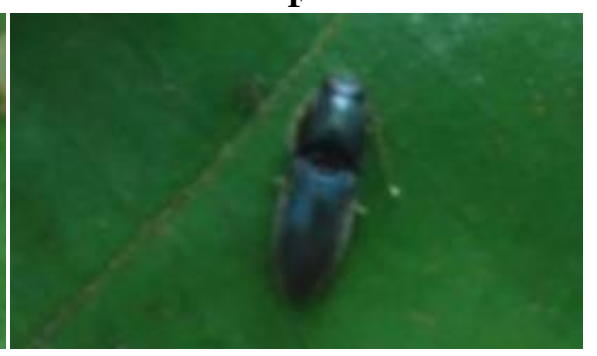

I

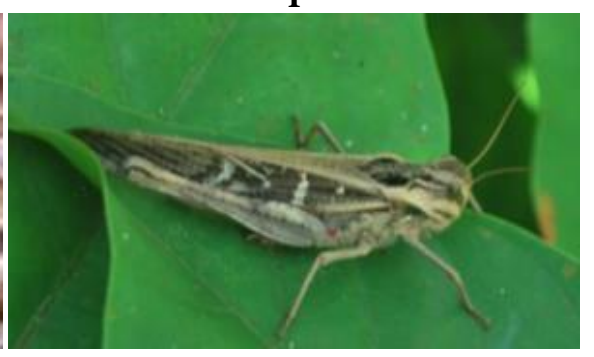

$\mathbf{L}$

Figure 3. Insect pest of: A-D. Lymantridae; E. Geometridae; F. Arctidae; G. Noctuidae; H. Limacodidae; I. Scarabaeidae; J. Chrysomelidae; K. Coccinellidae; L. Arcrididae; M-N. Unknown insect

The family of Noctuidae and Lymantriidae (Tussock moth) are a common pest of planted S. macrophylla in the study area. According to Anderson (1961), there was a large outbreak of hairy caterpillars on S. macrophylla tree in Sarawak and Brunei during the 1950s. Lymantriidae body is stout and bristly with urticating's setae. They are forestry insects and feed on the foliage of the woody plant and sometimes as a pest (Keena et al. 2008). However, there was no emerging severe pest problem in Dipterocarps because of resin production as protection for the trees. Several hairy insects were recorded as pests on the Dipterocarps tree, such as Calliteara pudibunda, Dasychira sp., Euproctis sp., Leucoma sp., Lymantria sp., and Orygia sp. (Hill 1997). Larvae such as Orgyia spp. were found feeding on $S$. macrophylla in a group on matured foliages at the lower crown during the first instar. Meanwhile, 
Helicoverpa sp. caterpillars are highly fed on young foliages. On the other hand, a Coleopteran Podontia sp. (Chrysomelidae) fed on the lower and upper branches of the tree. Small beetle (Chilocorus sp.) perforating small holes into the stem and living inside it.

In general, larva pests could be found on young and mature foliage (Hill 1997; Heinrichs 1998). However, the damages on foliage caused by larvae mainly occurred at the tree's lower crown rather than the upper crown. The damage was higher at matured foliage rather than young foliage. Young foliage is more protected than matured foliage in the forest system due to its chemical contents and physical appearance (Coley and Barone 1996; Dyer and Coley 2001). Some larvae were found to feed on foliage but took shelter under the layer of the bark, while others rolled the foliage for shelter.

Shamsudin (1991) reported that insect attacks on shoot did not cause mortality of tree except Shorea teysmanniana but led to several damages on the tree. However, the defoliation of the commercial dipterocarps tree's defoliation should not be taken lightly, as the defoliation may weaken the tree, thus highly amenable for deadly infestation. For example, the second borer caused damage such as Hoplocerambyx spinicornis (Pratap-Singh and Thapa 1988), which is reported to be a pest for Parashorea robusta, Parashorea malaanonan, P. stellata, Shorea siamensis, S. assamica, S. obtusa, S. robusta, Anisoptera glabra, and Hopea odorata (Elouard 1998). Some borers are not a threat to the tree itself, but they produce lower $\operatorname{logs}$ and timber prices and are useless for construction industries.

The foliage damage of the $S$. macrophylla tree had been described quantitatively in this study, where the $S$. macrophylla tree was defoliated mainly by an insect pest. The foliage damage on the $S$. macrophylla tree showed that the damage was critically higher during early age development. However, the damage has shown decrement from $63 \%$ to $33 \%$ at older ages. Therefore, this hypothesized that the age stands of the trees influenced the rate of defoliation on $S$. macrophylla by insect attack. The typical damage and insect pest of $S$. macrophylla had been identified and determined where most damage that occurred on the foliage of $S$. macrophylla was "hole damage," including necrosis, skeletonizing, and free feeding. The typical insect feeds on S. macrophylla were mainly from the hairy caterpillar of the Lymantriidae family (Lepidoptera), where it can be found at any age stage of the tree. The management of hairy caterpillars should be considered and monitored critically as this group can cause total damage to the tree, such as foliage loss and dieback. Further investigation on other possible causes which influenced the pest attack should be initiated to find solutions that may restrict the growth of planted $S$. macrophylla in the forest restoration program.

\section{ACKNOWLEDGEMENTS}

This research was financially supported by the Research Acculturation Grant Scheme (RAGS) RAGS/STWN/
02(1)/913/2012(14) from the Ministry of Higher Education, Malaysia, and partially supported by Grant-in-Aid from Japan Malaysia Association (JMA) for scientific research purpose. We wish to express our gratitude to the Director and staff of the Forest Department Sarawak for their supportive assistance during the duration of this study.

\section{REFERENCES}

Allard GB, Fortuna S, See LS, Novotny J, Baldini A, Courtinho T. 2003. Global Information on Outbreaks and Impact of Major Forest Insect Pest and Diseases. Food and Agriculture Organization, Canada.

Aluja M, Sivinski J, van Driesche R, Anzures-Dadda A, Guillén L. 2014. Pest management through tropical tree conservation. Biodiv Conserv 23: 831-853. DOI: 10.1007/s10531-014-0636-3.

Anderson JAR. 1961. The destruction of Shorea albida forest by an unidentified insect. Emp For Rev 40: 19-29.

Anon. 2002. Chapter 2: State of Environment and Policy Retrospective, 1972-2002. United Nations Publications, New York.

Battaglia M, Pinkard EA, Sands PJ, Bruce JL, Quentin A. 2011. Modelling the impact of defoliation and leaf damage on forest plantation function and production. Ecol Model 222: 3193-3202 DOI: 10.1016/j.ecolmodel.2011.06.017.

Cavaletto G, Mazzon L, Faccoli M, Marini L. 2019. Habitat loss and alien tree invasion reduce defoliation intensity of an eruptive forest pest. For Ecol Manag 433: 497-503. DOI: 10.1016/j.foreco.2018.11.028.

Chung AYC, Maycock CR, Khoo E, Hastie A, Nilus R, Majapun R, Kimjus K, CheyVK. 2013. New records of insect associated with Bornean endemic Dipterocarp seedling. J Trop For Sci 25 (1): 5-11

Coley PD, Barone, JA. 1996. Herbivory and plant defenses in tropical forests. Ann Rev Ecol 27: 305-335. DOI: 10.1146/annurev.ecolsys.27.1.305.

Daljeet-Singh K. 1975. A preliminary survey of insect attack on seedlings and saplings in Bukit Belata forest reserve. Malays For 38: 14-16.

Department of irrigation and drainage. 2010. Sarawak Hydrological Year 2010. Drainage and Irrigation Department, Sarawak.

Dyer LA, Coley PD. 2001. Tritrophic interactions in tropical versus temperate communities. In: Tscharntke T, Hawkins BA (eds). Multitrophic Level Interactions. Cambridge University Press, London.

Elouard C. 1998. Pests and Diseases of Dipterocarpaceae. Center for International Forest Research, Indonesia. Cifor, Bogor.

Heinrichs E. 1998. Plant Stress-Insect Interactions. A Wiley- Interscience Publications, Canada.

Hill DS. 1997. The Economic Importance of Insect. Chapman and Hall, London.

Howlett BE, Davidson DW. 2001. Herbivory on planted Dipterocarp seedlings in secondary logged forest and primary forest of Sabah, Malaysia. J Trop Ecol 17: 285-302. DOI: 10.1017/S0266467401001195.

Itoh A, Yakamura T, Ogina K, Lee H. 1995. Survivorship and growth of seedling from Dipterocarp species in tropical rainforest Sarawak. Ecol Res 10: 327-338. DOI: 10.1007/BF02347859.

Keena MA, Cote MJ, Grinberg PS, Wallner WE. 2008. World distribution of female flight and genetic variation in Lymantria dispar (Lepidoptera: Lymantriidae). Environ Entomol 37 (3): 636-649 DOI: 10.1603/0046-225X(2008)37[636:WDOFFA]2.0.CO;2.

Kirton LG, Cheng S. 2007. Ring-barking and root debarking of Dipterocarp saplings by termites in an enrichment planting site in Malaysia. J Trop For Sci 19: 67-72.

Lee HS, Itoh A, Kanzaki M, Yamakura T 1997. Height growth of Engkabang Jantong, Shorea macrophylla (De Vr.) Ashton, in plantation forest in Sarawak. Tropics 7: 67-80. DOI: 10.3759/tropics.7.67.

Lee SS. 2018. Observations on the successes and failures of Acacia plantations in Sabah and Sarawak and the way forward. J Trop For Sci 30: 468-475. DOI: 10.26525/jtfs2018.30.5.468475.

Marcais B, Breda N. 2006. Role of an opportunistic pathogen in the decline of stressed oak trees. J Ecol 94: 1214-1223. DOI: 10.1111/j.1365-2745.2006.01173.x.

Morrison H, Nunamaker C, Leblanc J, Giusti G, Nakamura G. 2007. Forest and disease. Forest Stewardship Series 16: 1-11. University of 
California Agriculture and Natural Resources. Publication \#8246, 11. http://anrcatalog.ucdavis.edu

Nair KSS, Mather G, Mohandas K, Menon ARR. 1986. A study of insect pest incidence in natural forest. Kerala Forest Research Institute, India

Nair KSS, Sumardi. 2000. Insect pests and diseases of major plantation species. In: Nair KSS (eds). Insect Pests and Diseases in Indonesian Forests: An Assessment of the Major Threats, Research Efforts and Literature. Center for International Forestry Research, Bogor, Indonesia.

Nair KSS. 2007. Tropical Forest Insect Pest: Ecology, Impact and Management. Cambridge University Press, UK.

Perumal M, Wasli ME, Ying HS, Lat J, Sani H. 2017a. Survivorship and growth performance of Shorea macrophylla (de Vriese) after enrichment planting for reforestation purpose at Sarawak, Malaysia. OnLine J Biol Sci 17 (1): 7-17. DOI: 10.3844/ojbsci.2017.7.17.

Perumal P, Wasli ME, Ho SY, Lat J, Sani H. 2017b. Association between soil fertility and growth performance of planted Shorea macrophylla (de Vriese) after enrichment planting at rehabilitation sites of Sampadi Forest Reserve, Sarawak, Malaysia. Intl J For Res 2017: 6721354. DOI: $10.1155 / 2017 / 6721354$.

Prastyaningsih SR, Hardiwinoto S, Musyafa, Dwi KCA. 2020. Diversity of termites (Isoptera) on industrial forest plantation of Eucalyptus pellita stands of tropical ecosystem in Riau, Indonesia. Biodiversitas 21 (11): 5498-5505. DOI: 10.13057/biodiv/d211158.

Pratap-Singh, Thapa RS 1988. Defoliation epidemic of Ascotis selenaria imparata Walk. (Lepidoptera: Geometridae) in Sal Forest of Asarori Range, West Dehra Dun Division. Indian For 114: 269-274.

Saunders ME, Peisley RK, Rader R, Luck GW. 2016. Pollinators, pests, and predators: Recognizing ecological trade-offs in agroecosystems. Ambio 45 (1): 4-14. DOI: 10.1007/s13280-015-0696-y.
Shamsudin I. 1991. A note on the coppicing ability of Shorea species in peat swamp in Peninsular Malaysia. J Trop For Sci 3: 301-303.

Tho Y, Norhara H. 1983. On insects associated with Kapur (Dryobalanops aromatica) and their status. Proceedings of the Symposium on Forest Pests and Diseases in Southeast Asia. BIOTROP Special Publication no 2. SEAMEO-BIOTROP, Bogor, Indonesia, 14-16 October 1981.

Tubby KV, Webber JF. 2010. Pests and diseases threatening urban trees under a changing climate. For Intl J For Res 83 (4): 451-459. DOI: 10.1093/forestry/cpq027.

Wargo PM. 1996. Consequences of environmental stress on oak: Predisposition to pathogens. Annals For Sci 53: 359-368. DOI: 10.1051/forest:19960218.

Wasli ME, Ambun DB, Kalu M, Sidi M, Nahrawi H, Elias H. 2020. Assessment on the growth performance of planted Dryobalanops beccarii at reforestation sites after implementation of selective $\begin{array}{llll}\text { girdling. Biodiversitas } 21 & \text { (5): 1880-1889. DOI: }\end{array}$ 10.13057/biodiv/d210514.

Wasli ME, Sani H, Ho SY, Perumal M, Zainudin ZA, Lat J, Lee PS. 2014. Preliminary assessment on the growth performance of Dryobalanops beccarii Dyer planted under enrichment planting technique at Gunung Apeng Forest Reserve, Sarawak, Malaysia. Kuroshio Sci 8 (1): 45-52.

Watt AS. 1997. Forest Management. Chapman and Hall, London.

Wormald T. 1992. Mixed and pure forest plantations in the tropics and subtropics. FAO For Pap. http://www.fao.org/3/ap421e/ap421e00.pdf.

Zulfiah A. 1998. Gangguan dan ancaman hama terhadap hutan tanaman industri di PT. Musi hutan Persada, Sumatera Selatan. In: Suratmo G, Hadi S, Husaeni EA, Rachmatsjah O, Kasno, Nuhamara ST, Haneda NF (eds). Proceedings Workshop Permasalahan dan Strategi Penggelolaan Hama di Areal Hutan Tanaman. Fakulti Kehutanan dan Jabatan Kehutanan, Bogor, Indonesia. [Indonesian] 